\title{
Strengthening the core business of farmers markets through strategic business planning
}

\author{
David J. Connell a* and Christopher Hergesheimer ${ }^{\mathrm{b}}$ \\ University of Northern British Columbia
}

Submitted August 30, 2013 / Revised February 23, March 1, March 3, April 18, and June 2, 2014 /

Accepted June 2, 2014 / Published online September 18, 2014

Citation: Connell, D. J., \& Hergesheimer, C. (2014). Strengthening the core business of farmers

markets through strategic business planning. Journal of Agriculture, Food Systems, and Community

Development, 4(4), 97-108. http://dx.doi.org/10.5304/jafscd.2014.044.017

Copyright (C) 2014 by New Leaf Associates, Inc.

\begin{abstract}
The current period of growth in the number of farmers markets is associated with higher demand for local food but also leads to more competition among farmers markets. Dealing with increased competition challenges the way that farmers markets are used to operating. In this commentary, the authors discuss how a business-oriented

a* Corresponding author: David J. Connell, Associate Professor, University of Northern British Columbia; 3333 University Way; Prince George, British Columbia V2N 4Z9 Canada; +1250-960-5835; david.connell@,unbc.ca

b Doctoral student, Faculty of Land and Food Systems, University of British Columbia; 2329 West Mall; Vancouver, British Columbia V6T 1Z4 Canada; c.p.hergesheimer@gmail.com

Note: Portions of this commentary were published as a guidebook, Selling at BC's Farmers' Markets: A Guide for New Farmer Vendors, for the British Columbia Association of Farmers' Markets.
\end{abstract}

approach to strategic planning may help farmers markets respond to industry-wide changes. We first focus on what we refer to as the core business of a farmers market, whereby a farmers market can view itself as a business entity that functions separately from its vendors. We extend this discussion to strategic business planning and how competitive analysis can be used to better understand and thereby strengthen a farmers market's position in an increasingly competitive marketplace. Ideally, a business-oriented perspective should not compromise the special qualities of a farmers market but serve to enhance these qualities and add to the growth and development of a farmers market. The insights in this commentary are drawn from the general experiences of the authors.

\section{Keywords}

farmers markets, strategic business planning, industry growth, competitive analysis 


\section{Introduction}

The number of farmers markets across North America has grown substantially over the past ten years. This growth, which is associated with wider acceptance, more customers, and increased product standardization, is viewed usually in positive terms for both farmers and people looking to buy locally produced seasonal foods. However, the increase in the number of farmers markets is also a catalyst for increased competition among farmers markets. This competition derives from existing markets expanding, new markets opening up, and the promoting of "local foods" by supermarkets and other food retailers. Thus, while the growth in farmers markets indicates a stronger local food movement it also challenges many of the current ways that farmers markets operate.

Corum, Rosenzweig, and Gibson (2001) were among the first to recognize the need for farmers markets to respond to the challenges of increased competition. They described a potential situation in which the weakest markets will be sifted out as the level of competition increases. To avoid this kind of situation, Colihan and Chorney (2004) state that farmers markets must learn to "work smarter." In this commentary, we present our view of how farmers markets can "work smarter" by adopting a more business-oriented approach to strategic planning.

To adapt to increased competition, and capture benefits of industry growth, businesses typically invest in planning. The function of planning in a general sense is to make a desirable future a visible part of today's decision-making processes (Connell, 2009). The primary aim is to gain a better understanding of where a business wants to be in the future and how to get there. But thinking like a business is not common among the management teams (board members and market managers) of farmers markets. Therefore, one aim of this commentary is to introduce business terms and concepts that can help members of management teams to consider their farmers market as a business entity with its own goals.

We believe that a business-oriented approach does not displace the foundational spirit of a farmers market as an arena for community development. Rather, we believe that thinking of a farmers mar- ket as a business can enhance its non-economic qualities by helping to focus on its strengths. In other words, we are not advocating a business approach at the expense of the unique qualities that make farmers markets special. In the face of increased competition, farmers markets must find creative ways to think about what they do best in order to strengthen these qualities rather than lose out to businesses disguised as farmers markets. Within the context of strategic planning, we will discuss what we see as the core business of farmers markets. We then discuss how competitive analysis can be used to better understand and thereby strengthen a farmers market's position in an increasingly competitive marketplace.

\section{Strategic Business Planning}

A typical outcome of strategic planning by a business facing the challenges of industry growth is a focused marketing strategy that differentiates its offerings from other competitors. This approach seems reasonable for farmers markets as well. Doing so, however, requires farmers markets to shift from organizational planning to strategic planning.

Like most non-profit organizations, farmers markets focus on their vision, mission, objectives, goals, and action plans. That is, they focus on organizational planning. The resources available that support organizational planning among farmers markets are extensive, with a broad range of topics and analytical tools (e.g., Brushett, 2008; de Beaufort \& Wagner, 2009; Govindasamy, Zurbriggen, Italia, Adelaja, Nitzsche, \& VanVranken, 1998; Jolly, 2005; Ostrom \& Lyons, 2007; Schmit \& Gómez, 2011; Sneed \& Fairhurst, 2010; Stegelin, 1997; Wallace Center (2007a, $2007 \mathrm{~b})$. The strength of these resources rests upon their ability to encourage management teams to think critically about a desirable future for their farmers markets.

The kind of organizational planning that focuses on mission statements and action plans, while very effective in starting a farmers market, is too broad to deal with the specific challenges of industry growth and increased competition. Quite often, members may all agree on the broad mission of the farmers market but disagree as to how to get 
there, which can lead to conflict. Strategic planning includes the same elements as organizational planning but also has an explicit focus on the structure and dynamics of the external environment. In a business context, this means focusing on the current position of a business in the marketplace and where it wants to be. This kind of planning requires one to look at how a business functions as part of a whole vis-à-vis its competitors, as well as regulators and other external dynamics. Strategic business planning, therefore, has two defining components: an orientation to the future and an external focus on the competition. For farmers markets that have done organizational planning, a complement of business-oriented strategic planning adds a level of analysis that can help generate new insights.

As part of any planning process, it is essential that everyone involved has a common starting point; that is, everyone needs to be "on the same page." A likely consequence of not having a common perspective is that the process can lose its focus and devolve into what seem like endless arguments because the group lacks a common framework for reconciling differences. The alternative is to invest time and effort up front in order to ensure that the foundational purpose of the market is clearly understood by everyone involved. However, one of the primary obstacles to strategic business planning that we have found among farmers markets is that they don't have the words and concepts to be able to think about their farmers market as a business. Without a shared understanding of the core business of a farmers market it is not possible to engage in a productive strategic business planning process.

\section{The Core Business of Farmers Markets}

It is common to associate farmers markets with a broad range of goals, interests, and functions, such as selling local foods, supporting the local economy, and serving the community. For example, Colihan and Chorney (2004) open their book by quoting Agriculture and Agri-food Canada (AAFC): "Farmers' markets are about more than the sale of agricultural commodities. They are about community, food, friends, and sense of sharing" (AAFC, 2002, p. 13, cited in Colihan \& Chorney, 2004, p. 15).
Likewise, Corum et al. (2001) suggest possible multiple "primary goals" of a farmers market, e.g., to build community, to help local farmers, provide food retail services to inner city residents, and preserve farmland. While these possible goals, interests, and functions accurately speak to characteristics of farmers markets, we question whether any of them define the core business of a farmers market. As Brushett (2008, slide 18, emphasis added) asks of farmers markets, "What business are you really in?"

Among the definitions of farmers markets presented by associations and government agencies one common element stands out: the integral role of direct sales from producer to consumer. The fresh and local qualities of products are also emphasized among the definitions, as is the physical element, which can be a place, space, building, common area, common facilities, centralized location, etc. From these ideas it appears that the core business of a farmers market is about direct sales of local fresh food on a recurring basis in a physical location.

While general definitions help to describe farmers markets, they do not address their function. For example, Corum et al. (2001) identify two major functions of farmers markets: to support local farmers and provide customers with produce. These two functions, they point out, "can erupt as conflicting goals, leading to a philosophical and practical split within the ranks of farmers, managers, and boards" (p. 132). They then conclude that "neither school will necessarily win the debate" (p. 133). But perhaps it is not for either school to necessarily win. As Lohr, Diamond, Dicken, and Marquardt (2011) state, "The viability of individual markets depends on attracting sufficient numbers of vendors and customers. Farmers markets must attract enough vendors to offer the quantity and variety of products needed to retain customer interest. At the same time, the markets must also attract enough customers to maintain vendor interest and participation" (p. 1). These accounts of farmers markets more clearly specify that the function of a farmers market is about bringing farmers and shoppers together such that the needs of both are met. This function suggests that the core business of farmers markets reflects a three-part rela- 
tionship: a farmers market serves to match farmers who want to sell directly to customers with shoppers who want to buy food directly from farmers. As part of this three-way relationship, farmers must sell enough products at the right price and customers must be able to buy what they want at the right price. This is what we refer to as the farmermarket-shopper match. In this sense, both the vendors and the shoppers are "customers" of a farmers market. As King (2006, n.p.) states succinctly, "You need both vendors and customers to make a market work. Make sure you don't neglect one for the other."

The idea of a farmers market serving to match farmers with shoppers leads to a more concise definition of the core business of a farmers market, as follows: The core business of a farmers market is to profit by bringing vendors and market shoppers together in a unique setting. In this definition we use the term "profit" to emphasize that a market has an explicit intent to benefit from its match-making service. The term "profit" also emphasizes that a farmers market can be viewed as a business entity. We also add "in a unique setting" to the statement to infer a particular quality of farmers markets as a special place of interaction, which focuses attention on the unique qualities of the setting.

A shared understanding of the core business of farmers markets provides the foundation for strategic business planning. It provides a common language that helps people to think and talk about farmers markets in business terms. This shared understanding of the business of a farmers market also provides a common point of reference, a place from which members of the management team can look both inward and outward. Internally, a market can examine how a business perspective can enhance its triple bottom line that includes social and environmental goals and objectives.
Externally, from this common perspective it is much easier to discuss and agree upon what makes farmers markets different from each other, what industry they participate in, and who their competitors are.

\section{A Typology of Farmers Markets}

While farmers markets may look and feel the same, many external factors influence the kind of match that a farmers market can provide. The customer base involves factors such as income, shopping patterns, and preferences. Likewise, there is diversity among farmers, including products, production methods, size, and marketing channels used. Other factors include the size of the farmers market (very small to very large) and the presence of tourists. More tourists may translate into more visitors but not necessarily more shoppers. More tourists may also mean more artisan sales than craft sales, which increases the average amount spent by market shoppers, but not necessarily on farm products. As such there are many factors that influence how a particular market appeals to both producers and consumers, thus affecting how the farmers market serves as a particular match.

It is possible to analyze how external factors influence the core business of a farmers market by
Figure 1. Typology of Farmers Markets

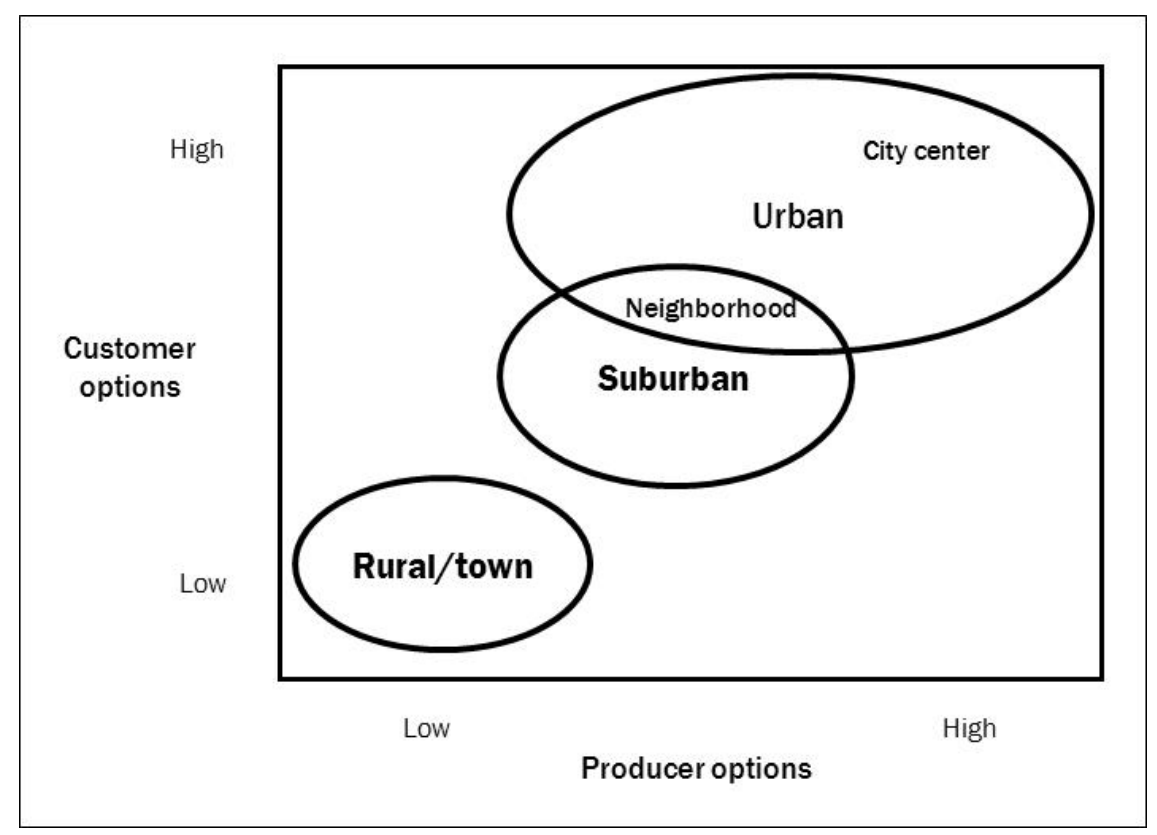


examining a combination of two overriding factors: (1) the options available to producers to sell via direct marketing channels; and (2) the options available to consumers to purchase directly from farmers. These two factors play out differently in different locations. The potential combinations of producer and consumer options suggest a typology of farmers markets, as illustrated in Figure 1 and described in Table 1. Urban areas include both inner city and city neighborhoods. City neighborhoods and some suburban areas may overlap. Town markets are found in rural and isolated areas, and include small cities.

Although this typology of markets might seem simple, it also provides several insights. First, the combination of options defines types of farmers markets rather than the market's location, per se. For example, a significant insight that emerges

Table 1. Characteristics of Farmers Markets by Type

\begin{tabular}{|c|c|c|}
\hline Urban & Suburban & Rural/Town \\
\hline $\begin{array}{l}\text { Description: Located in high popula- } \\
\text { tion centers. Includes all markets in } \\
\text { Vancouver and Victoria and small } \\
\text { cities such as Kelowna, Kamloops } \\
\text { and Prince George. May also include } \\
\text { markets in larger suburbs in the } \\
\text { southwest region. }\end{array}$ & $\begin{array}{l}\text { Description: Located within a short } \\
\text { drive of urban centers. Includes many } \\
\text { areas in the Lower Mainland as well } \\
\text { as around Victoria; also present } \\
\text { around smaller cities. Suburban } \\
\text { locations have a variable range of } \\
\text { producer and consumer options. }\end{array}$ & $\begin{array}{l}\text { Description: Located in small towns } \\
\text { or isolated areas with few or no other } \\
\text { markets nearby. Rural areas such as } \\
\text { the Central Interior, most of Northern } \\
\text { BC, areas of the Kootenays, the } \\
\text { North Coast, and the Rockies oper- } \\
\text { ate town markets. Town markets } \\
\text { make up almost half of the markets } \\
\text { in the province. Town markets pro- } \\
\text { vide the smallest range of options to } \\
\text { both producers and consumers. }\end{array}$ \\
\hline
\end{tabular}

Consumer options: Have access to a variety of other direct marketing channels (CSA, food box delivery, Upick) that offer convenient, alternative outlets to purchase local food direct from farmers. Also have access to many retail establishments.
Customer options: Often compete with CSAs, farm stands, and U-pick operations which tend to be located in suburban areas. Specialty and retail outlets offering local food are not as prevalent as in urban centers.
Consumer options: While many town markets have a committed customer base, town markets provide one of the only access points for farm products that meet consumer ideals. Although the profile of alternative direct marketing options is rising, town markets tend to be the primary point of contact between consumers and local agricultural products.

Producer options: For vendors, town markets often serve as the only available marketing channel for smallscale production. Market power is restricted by the lack of economically viable marketing options.
Producer options: Farmers have access to a broad spectrum of customers and marketing options, ranging from restaurants to specialty retail establishments and institutions.
Producer options: Being located closer to areas of production, producers at suburban markets often use the market as a promotional tool to attract business to local farm stands. However, the prevalence of suburban "farm markets" that stock out of season and offer cheap products offers a distinct challenge to producers in terms of pricing and convenience.
Challenges: Allocation of spaces in urban markets tends to be limited and controlled. Access requires advance planning and dedication. Stall fees tend to be higher. Consistent production and attendance, innovation, and price and product presentation are very important to attract and retain customers.
Challenges: Suburban markets are often located within range of other markets and many operate on the same day and during the same hours, distributing the customer base to a number of sites.
Challenges: Markets face challenges with building and maintaining a consistent base of primary producers with a wide range of product offerings. Consistency and quality of products are central to market growth and stability. 
from this typology relates to levels of competition among farmers markets. Generally, a high number of options for buying local food for both producers and consumers is associated with higher levels of competition, and this combination of options tends to occur in urban centers. This insight is consistent with what Lohr et al. (2011) found in their analysis of competition zones for vendors and customers, which deals explicitly with the consequences of overlapping markets as the number of farmers markets grows. They found that the level of competition for vendors is most intense in urban areas because farmers markets must compete with each other directly for both vendors and shoppers. Lohr et al. conclude that location is the "most accurate indicator of high-intensity competition” (p. 4), as also captured in the three-part typology of farmers markets.

The sets of options available to both producers and consumers effectively define key elements of a farmers market's external environment. The typology highlights how different sets of options lead to different outcomes, which create opportunities for a farmers market to strategically choose how it formulates its own match. To take strategic business planning to a greater level of detail a management team needs to examine its farmers market in relation to the industry within which it competes, identify who their competitors are, analyze what their market position is, and explore how they can strengthen themselves vis-à-vis their competitors. In the business world, this part of strategic planning is called competitive analysis.

\section{Competitive Analysis}

The aim of completing a competitive analysis is to analyze an industry as a whole to understand its potential evolution, its competitors, and a firm's own position in the industry (Porter, 1980, 1985). The objective is to understand what factors influence relations among competitors.

While some concepts and analytical tools related to competitive analysis appear in the broader literature on the agricultural sector, these studies tend to be technical studies of specific industries or commodities with limited transferability to farmers markets. There are some exceptions which are related directly to farmers markets. Sneed and
Fairhurst (2010) use activity system mapping as a basic level of competitive analysis for farmers markets. Lohr et al. (2011) focus on mapping competition zones for vendors and customers, which deals explicitly with the consequences of overlapping markets as the number of farmers markets grows. With specific regard for competitive strategy, Lohr et al. point out the need for differentiation from competitors as a basis for market survival. They mention such strategies as operating on different days from nearby markets, extending the operating season, and building upon location-specific features (e.g., nearby businesses, parks, access to parking). Another exception is Lass, Lavoie, and Fetter (2005), whose study of Community Supported Agriculture (CSA) is directly relevant to farmers markets. They conclude that CSA operations have the ability to turn customer loyalty and ideological relations with customers into profits. However, as the authors discovered, few CSA operations actually use this market power to generate greater profits, which keeps prices lower for their customers. Given the close relationship between CSAs and farmers markets, it is reasonable to assume that these results can also apply to farmers markets.

Competitive analysis centers on relations among individual participants in an industry, which is referred to as market position. One way to analyze market position is to complete what is called a strategic group analysis, which is a tool that can be used to help visualize market positions of competitors. This analytical tool is used to identify who a business's direct competitors are and on what basis they compete (Porter, 1980). The aim is to focus on the business models of the major players in the industry. A business model refers to the underlying rationale of how a business is organized, how it operates, and the strategies it uses to maintain value.

Completing a strategic group analysis requires three steps. The first step is to specify the industry. The second step is to identify the businesses competing in the industry. The third step is to identify the most important factors or strategies that these businesses use to compete with each other.

The first step, to identify the industry in which farmers markets participate, is not as easy as it 
Figure 2. Strategic Group Map: Food Retail

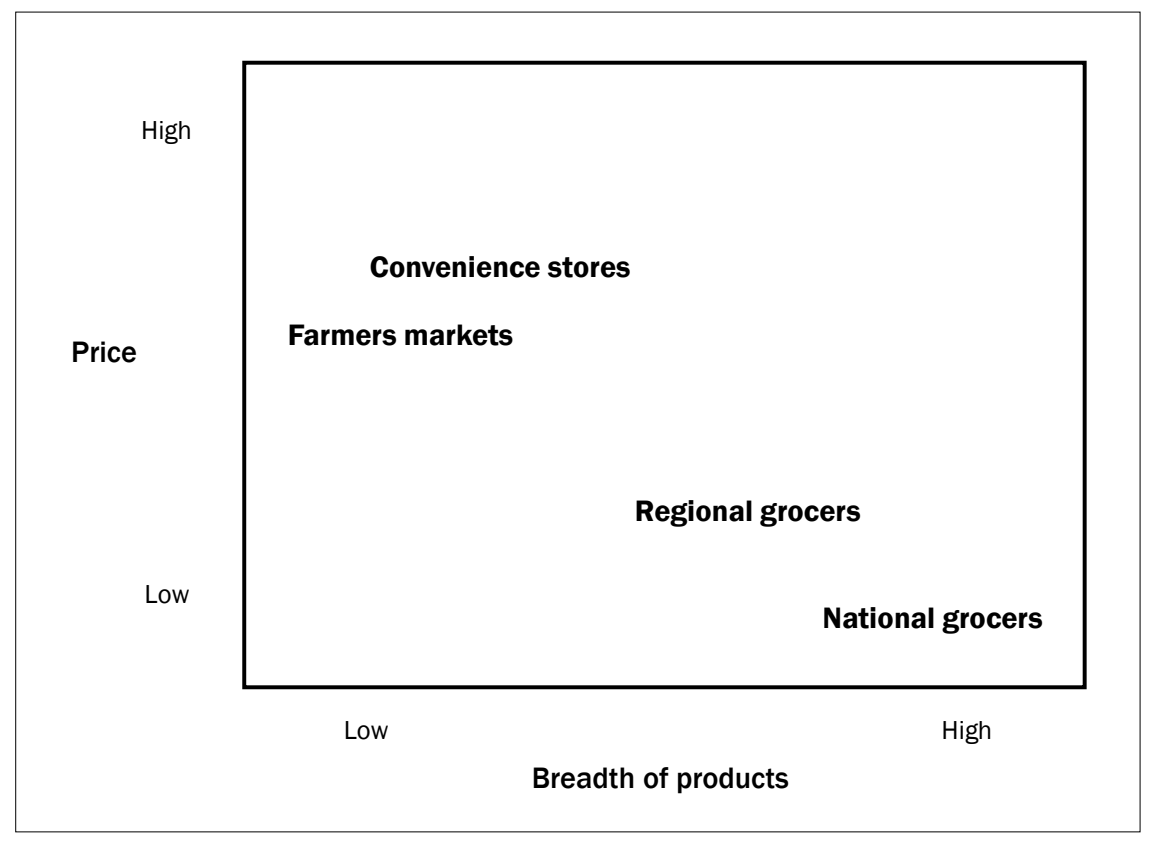

Figure 3. Strategic Group Map: Food Retail and Relative Size

The size of font is for illustrative purposes only; it is not based on real market share.

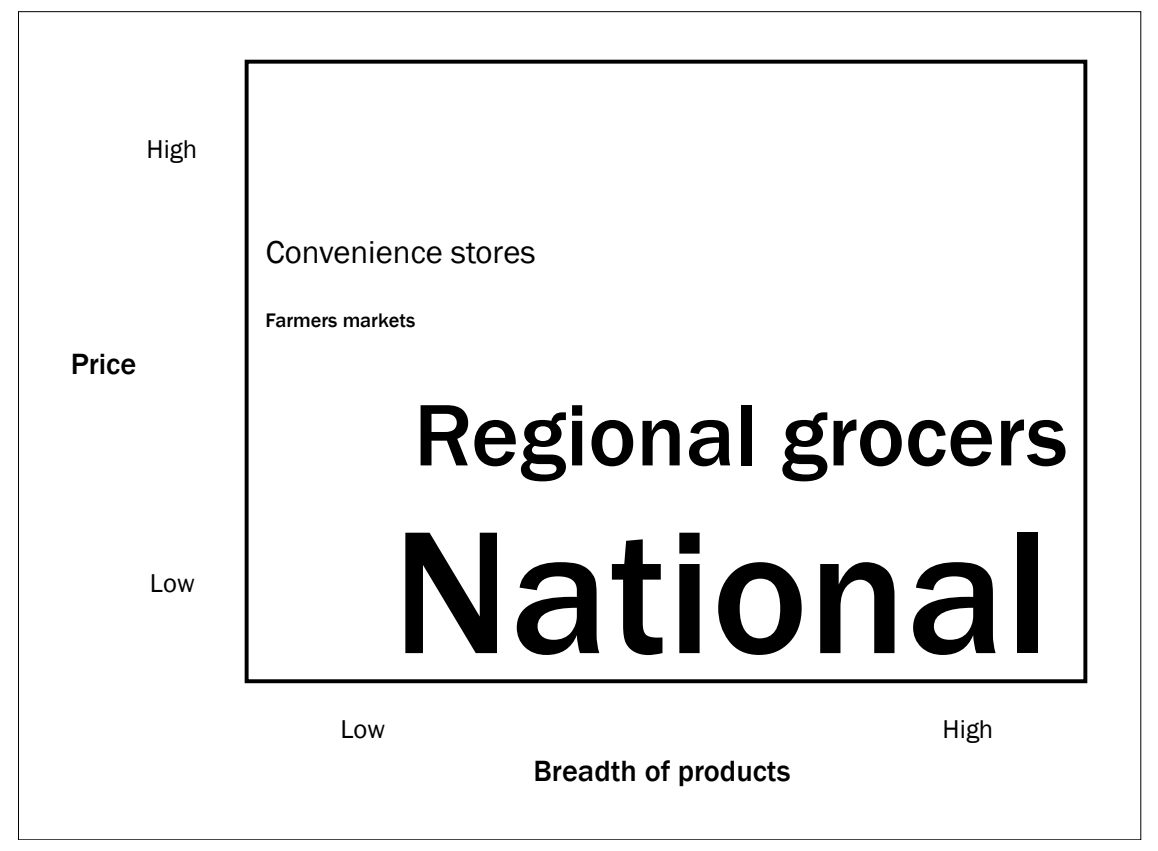

stores, and convenience stores, as well as all forms of direct marketing (e.g., farmers markets, farm gate sales, CSAs, U-pick, internet sales). In simple terms, we can analyze the food retail sector based on two factors or strategic dimensions: price (which is closely linked with volume) and breadth of products and services. In Figure 2, the two dimensions of price and breadth of products help to visualize the relations among competitors in the food retail industry. National (and international) food retailers are clearly focused on low prices (and very high volumes), with regional food retailers doing their best to compete with them. Simultaneously, the largest retailers have far broader ranges of products and services compared to convenience stores and farmers markets. The smaller retailers will never be able to compete on these terms with the bigger retailers. The reality of the situation is better illustrated in Figure 3, which is a modest attempt to incorporate the relative size of each business into the analysis.

As the competitive analysis of the food retail industry shows, farmers markets cannot compete directly with big, national retailers. But might appear because it is possible to analyze farmers markets as participants in different industries. For example, farmers markets can be analyzed as part of the "food retail" sector, which includes, for example, grocery stores of all sizes, health food farmers markets need not accept this situation. Every business has an opportunity, at least to some extent, to choose and shape the industry in which it wants to compete, and can choose to think of its industry in different terms. Thus, while there is 
merit to considering different industries in which farmers markets are players, redefining the industry as a farm-direct food retail operation positions farmers markets within a niche segment of the food retail sector that is relatively small and specialized.

By changing the industry we also change the strategic dimensions that define who are the most direct competitors with farmers markets and on what basis they compete. For example, we can consider the following two factors: (1) the relationship with the farmer (personal to impersonal); (2) the social experience (low to high). Both factors account for the primary ways that farmers markets compete with each other and their competitors. In this way, re-defining the industry in which farmers markets participate effectively changes the competitive landscape, as shown in the strategic group analysis of the farm-direct food retail industry (Figure 4). In this niche industry segment, we can more clearly see that farmers markets form a strategic group with CSAs, farm gate sales, U-pick, and internet sales. Furthermore, we can also see important differences within this strategic group, with CSAs providing the most personal relation with farmers but not the same social experience. At the same time, these direct competitors may also be farmers market vendors, which presents some interesting dynamics. What is in the best interest of the farmer who sells at a farmers market but also has a CSA program may or may not be in the best interests of the farmers market.

As also shown in Figure 4, there is a group of indirect competitors, which includes grocery stores and other food retail outlets. Although the businesses among these indirect competitors can never replicate the special qualities of farm direct marketing, they certainly try, as evident by the increasing use of in-store profiles of local farmers and use of the "farmers market" brand. Companies usually com- pete with each other based on price, quality, and innovation. When there are many players of about the same size with similar products, then rivalry can be intense. And when the prospect for attracting new customers is low, because of a lack of growth in the industry, for example, then companies can only gain customers by competing directly for the same pool of customers. The result of this intense competition is low returns, because the cost of competing, whether by price, advertising, or innovation, is high. Based on our experience, we have found that competition in the farmdirect food retail industry is focused less on price and more on features such as quality of the food product, consistency, and reliability of vendors, as well as sociability of the venue. These factors tend to reduce the level of rivalry among farmers markets. Still, rivalry can come to the surface when the trade area of different markets overlap; that is, when two or more markets draw from the same population for its shoppers. This increased level of rivalry is evident in the study of competition zones by Lohr et al. (2011). Rivalry can be more heated when it comes to recruiting new vendors when the latter are in short supply.

Our analysis of the relations among farmers

\section{Figure 4. Strategic Group Map: Farm-Direct Food Retail}

The solid line shows a strategic group. The dotted line shows indirect competitors.

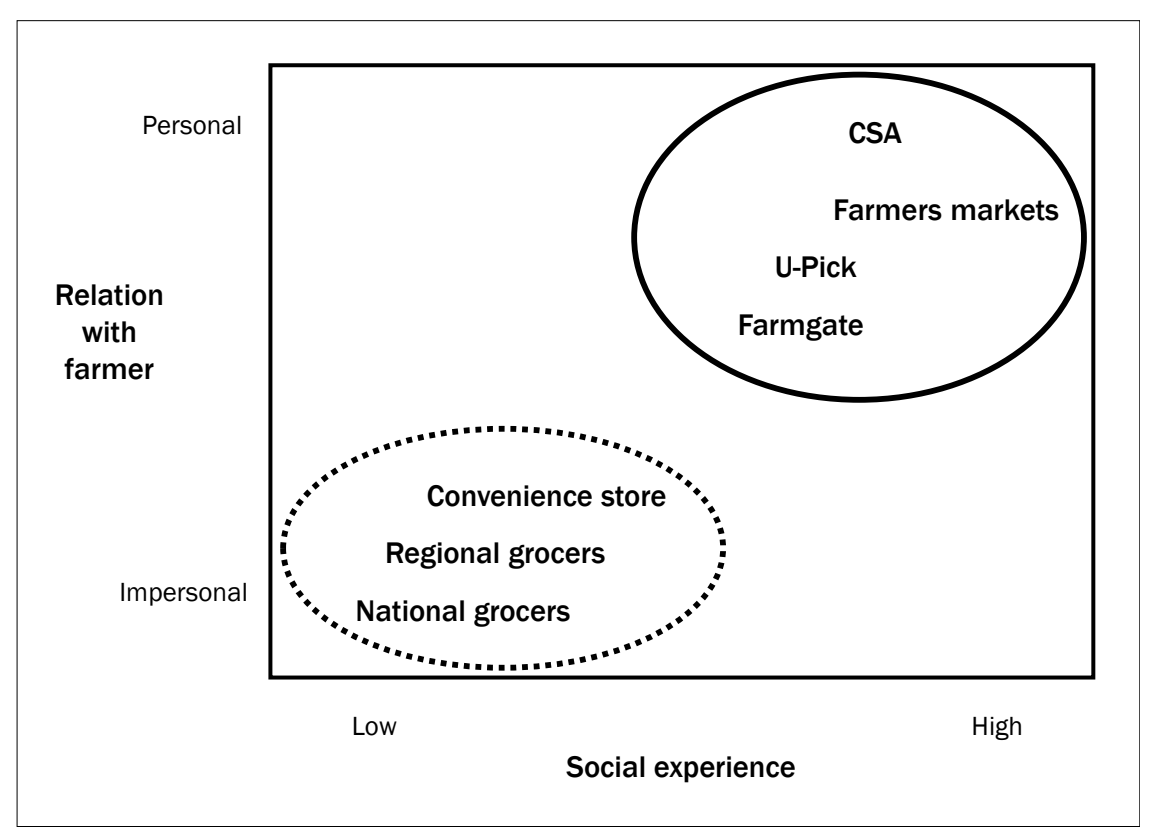


markets and their competitors reveal that customer loyalty and rivalry/collaboration among existing vendors are two important characteristics that define competitive relations. Customer loyalty is related to both the power of buyers and threat of new entrants. Generally, farmers market shoppers tend to have a high level of influence over prices because often they can easily switch to another farmers market or marketing channel. As a counter to this high level of market power among shoppers we found that customer loyalty provided farmers markets with an advantage. This is consistent with the factors that Lass et al. (2005) found: higher customer loyalty improved a CSA's ability to capture more profits. "[T] he nature of their products, i.e., fresh organic vegetables produced from a known source, is such that consumer loyalty and 'brand' recognition make consumers captive to a given farm” (p. 5). Likewise, Youngs' (2003) investigation of farmers markets in northwest England found that customer loyalty was an important part of their success.

The level of rivalry/collaboration among vendors is directly related to the intensity of competition among existing vendors. When vendors are more willing to collaborate for the benefit of the market as a whole, they are also less likely to compete with each other over prices. When considered in the context of the three types of farmers markets we discussed as part of our typology (Figure 1), and as Lohr et al. (2011) found, rivalry is highest among urban markets, primarily because the markets are closer together and shopper traffic is typically higher. As Govindasamy et al. (1998) note, although rivalry among vendors and between vendors and local retailers is not serious in general, rivalry among farmers is a serious problem in some cases. Stegelin (1997) also notes that the level of co-operation among producers in an area should be considered as part of a market feasibility study.

\section{Looking Ahead and Moving Forward}

If the farm-direct food retail industry follows a typical industry life cycle, there will be a shakeout as the industry moves through its present stage of growth. This shakeout could mean that more difficult decisions are ahead for farmers markets as they respond to challenges of increasing competition, recruiting new farmer vendors, and satisfying increasing demands for an "authentic" shopping experience. Under these circumstances, analytical tools that are designed to help businesses respond to these changes can also support a farmers market's strategic planning process by helping to make sense of the farm-direct food retail industry as a whole and of how to put a farmers market in the best position to be successful.

Herein are some important benefits of a business-oriented approach to strategic planning. Focusing on the core business of a farmers market helps to answer the question, "What is it that we really want to do?" This helps management teams deal with the practical functioning of the farmers market and provides language that members can use to engage in detailed discussions about how to strengthen their farmers market. Focusing next on market position provides a visual tool to help facilitate a discussion about the farmers market's current position. This is a good point in the planning process to discuss the farmers market's strengths and weaknesses as well as opportunities and threats (i.e., SWOT analysis) that define their core business and improve their position in the marketplace. By defining the context and identifying direct competitors, a competitive analysis helps to distinguish more clearly between factors internal to the farmers market (strengths and weaknesses) and factors external to the farmers market (threats and opportunities).

This work leads to the next critical question in the strategic planning process: "Now that we understand our position in the marketplace, where do we want to be in five years?" Herein lies the value of a strategic group analysis. If a management team has done the work to capture their farmers market's position vis-à-vis its competitors in a chart like Figure 4, then it is much easier to ask where, in five years' time, does the market want to be. In other words, does a farmers market want to position itself up or down or left or right on the two axes? How important is it for the market to promote personal relations between its customers and its vendors? What can the market do to maintain or improve the experience of shopping at the market? These are the kinds of questions that 
management teams should ask themselves as part of a strategic business planning process. The answers to these questions can be wide-ranging, resulting in anything from significant shifts to subtle changes in how a farmers market operates.

One of the most effective ways to translate insights gained from a strategic business planning process into decisions is to consider changes to policies. For some farmers markets, policies are viewed only as a set of rules and regulations for managing vendors. However, when considered in conjunction with an analysis of market position in the farm-direct food retail industry, policies change from tools of control to tools for turning a farmers market's competitive strategy into a competitive advantage.

Several policies stand out as particularly important for strengthening market position. These include staffing of vendor tables, cooperative selling arrangements, vendor mix, and re-selling produce. For example, if a farmers market has reselling policies that permit someone other than the farmer to sell the farm's products, then this reduces the level of direct interaction between farmer and customer, thus changing the relation with the farmer and moving the market down the vertical axis. The quality of social experience is influenced less directly by policies, but policies that affect the look and feel of a market, such as a policy (or lack thereof) to limit the proportion of non-food vendors, can alter the quality of the shopping experience. Each one of these policies may hinder or help a farmers market's ability to compete in the farm-direct food retail industry.

As we have tried to demonstrate through this discussion, there are valuable opportunities in implementing a business-oriented approach to strategic planning. Based on our experiences working with farmers market management teams, we have found that using business concepts as a basis for strategic planning helped to change the way they understood their farmers market operations As one person told us, "Even after thirty years, I was able to see the market from a new perspective." Another person stated, "It opened them [members of the management team] up to a project over the winter in which we took a much deeper look at the market as a business. They are slowly prioritizing areas of business development initiatives and developing projects to enhance the market as a business entity." While a businessoriented approach to strategic planning can benefit any farmers market, it may be most effective for markets facing the highest levels of competition, which are often located in urban areas.

However, while there are benefits to strategic business planning there are also significant challenges. As mentioned above, some members of farmers markets have not thought about their market in business terms before and may find the planning process difficult. In addition, people have expressed concern about viewing the markets strictly in business terms. Central to the concerns expressed by market management teams with whom we have worked was the potential to compromise the key character of the farmers market, as reflected in the following statement by one member of a management team:

The beauty of Farmers' Markets is their simplicity and purity. The ritual baskets of fresh produce are timeless, and is the foundation of the market. The market must remain, foremost, as a simple connection between the community and their food. If this connection becomes overly riddled in technology, it will lose the key to its foundation.

An additional concern relates to the difficulty of changing one's perspective. As one person stated, "Change can sometimes be slow and painful." The difficulty stems from a combination of introducing new ideas that are "outside of the comfort realm" of board members and of having board members who are not open to these new ideas. Consequently, "It will either take time to make the adjustment with the present group, or they will have to add some new talent with expertise in business to the Board to help with the transition.” A related challenge, the significance of which cannot be overstated, concerns the regular turnover among volunteer board members and the possible need to orient new members repeatedly to a business approach. Consequently, the knowledge and experience gained from going through a 
thorough planning process can be lost quickly because of turnover within the management team. One way to mitigate this potential loss is to ensure that detailed notes are recorded throughout the planning process. Finally, all of the possible challenges facing farmers market management are exacerbated when the work is done by only a small number of people. This has the potential to limit the generation of new ideas and can lead to biased decisions.

Ideally, a business-oriented perspective should not compromise the special qualities of a farmers market but serve to enhance these qualities. At the same time, we believe that a business-oriented approach to strategic planning must not be rejected without serious consideration of the potential contributions such a perspective can add to the growth and development of a farmers market, especially during a challenging period of industry growth.

\section{Acknowledgements}

The authors thank the British Columbia Association of Farmers' Markets for their support of this research and the members of the farmers markets who shared their experiences and insights with us.

\section{References}

Brushett, L. (2008). Show me the money: Business planning for farmers markets. South Deerfield, Massachusetts: Cooperative Development Institute. Retrieved from http://www.ams.usda.gov/AMSv1.0/getfile?dDoc Name $=$ STELPRDC5071518

Colihan, M. A., \& Chorney, R. T. (2004). Sharing the harvest: How to build farmers' markets and how farmers' markets build community! Brighton, Ontario: Epic Press.

Connell, D. J. (2009). Planning and its orientation to the future. International Planning Studies, 14(1), 85-98. http://dx.doi.org/10.1080/13563470902741609

Corum, V., Rosenzweig, M., \& Gibson, E. (2001). The new farmers' market: Farm-fresh ideas for producers, managers, and communities. Auburn, California: New World Publishing.

de Beaufort, N., \& Wagner, K. (2009, June 9). Strategic planning in the real world: How to put no staff, no money, and big dreams to work for your organization [Webinar]. Farmers Market Coalition. Retrieved from http://www.youtube.com/ watch?v=L5eIkTfggjA
Govindasamy, R., Zurbriggen, M., Italia, J., Adelaja, A., Nitzsche, P., \& VanVranken, R. (1998). Farmers' markets: Managers' characteristics and factors affecting market organization (P-02137-8-98). New Brunswick, New Jersey: N.J. Agricultural Experiment Station. Retrieved from http://dafre.rutgers.edu/docu ments/ramu/fm_mn.pdf

Jolly, D. (Ed.) (2005). Starting a new farmers market. The Farmers Market Management Series: Vol. 1. Davis, California: UC Small Farm Center. Retrieved from http://sfp.ucdavis.edu/ files/144703.pdf

King, A. (2006). Starting a farmers' market the right way. Kutztown, Pennsylvania: Rodale Institute. Retrieved from http://newfarm.rodaleinstitute. org/features/2006/0206/frmmrkt/king.shtml

Lass, D. A., Lavoie, N., \& Fetter, T.R. (2005). Market power in direct marketing of fresh produce: Community supported agriculture farms (Working Paper No. 20052). Amherst, Massachusetts: University of Massachusetts at Amherst, Department of Resource Economics. Retrieved from http://scholarworks.umass.edu/peri working papers $/ 200 /$

Lohr, L., Diamond, A., Dicken, C., \& Marquardt, D. (2011). Mapping competition zones for vendors and customers in U.S. farmers markets. Washington, D.C.: U.S. Department of Agriculture, Agricultural Marketing Service. Retrieved from http://www.ams.usda.gov/AMSv1.0/getfile?d DocName=STELPRDC5094336

Ostrom, M., \& Lyons, Z. D. (2007). W ashington State farmers market manual (Publication No. AGR PUB 200-189). Olympia, Washington: Washington State Department of Agriculture Small Farm and Direct Marketing Program and Washington State University Small Farms Program. Retrieved from http://agr.wa.gov/Marketing/SmallFarm/docs/ FMM1.pdf

Porter, M. E. (1980). Competitive strategy: Techniques for analyzing industries and competitors. New York: Free Press.

Porter, M. E. (1985). The competitive advantage: Creating and sustaining superior performance. New York: Free Press.

Schmit, T. M., \& Gómez, M. I. (2011). Developing viable farmers markets in rural communities: An investigation of vendor performance using objective and subjective valuations. Food Policy, 36(2), 119-127. http://dx.doi.org/10.1016/j.foodpol.2010.10.001 
Sneed, T.S., \& Fairhurst, A.E. (2010). From the boardroom to the farmers' market: Using activity system mapping to explore a farmers' market competitive advantage. Journal of Agriculture, Food Systems, and Community Development, 1(1), 149-159. http://dx.doi.org/10.5304/jafscd.2010.011.015

Stegelin, F. (1997). Establishing and operating a community farmers' market. Lexington, Kentucky: University of Kentucky, College of Agriculture Cooperative Extension Service. Retrieved from http://www.ams.usda.gov/AMSv1.0/getfile? $\underline{\mathrm{dDocName}=\text { STELPRDC5062524 }}$

Wallace Center (2007a). Getting started with farmers' markets. Arlington, Virginia: Henry A. Wallace Center and
Winrock International. Retrieved from http://www.wallacecenter.org/resourcelibrary/ getting-started-with-farmers-markets

Wallace Center (2007b). Recruiting vendors for a farmers' market. Arlington, Virginia: Henry A. Wallace Center and Winrock International. Retrieved from http://www.thegreenhorns.net/wp-content/ files $\mathrm{mf} / 1340375660$ RecruitingMembersfora FarmersMarket WallaceCenter.pdf

Youngs, J. (2003). Consumer direct initiatives in North West England farmers' markets. British Food Journal, 105(8), 498-530.

http://dx.doi.org/10.1108/00070700310497273 